\title{
УГОАОВНЫЙ ПРОЦЕСС
}

\section{ПРОБЛЕМНЫЕ ВОПРОСЫ ОТКАЗА В ВОЗБУЖДЕНИИ УГОЛОВНОГО ДЕЛА}

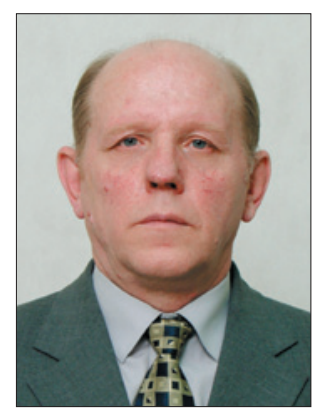

Одним из требований соблюдения прав человека в сфере уголовного судопроизводства является своевременное возбуждение уголовного дела. В связи с этим, деятельность по рассмотрению сообщений о преступлениях должна отвечать требованиям законности и обоснованности. Обоснованность обеспечивается строгим соблюдением требований уголовно-процессуального закона при собирании, проверке и оценке фактических данных, положенных в основу процессуального решения 1 .

В то же время, при возбуждении уголовных дел нарушения требований закона весьма распространены. Они совершаются как на этапе приема сообщений о преступлениях (сокрытие преступлений от учета; отказ в приеме заявления под различными предлогами), так и при предварительной проверке сообщений о преступлениях и принятии процессуальных решений (необоснованный отказ в возбуждении уголовного дела; квалификация уголовно наказуемых деянии как административных правонарушений; несвоевременное принятие процессуального решения и т. п.) $)^{2}$.

1 См.: Белозеров Ю. Н., Чувилев А. А. Проблемы обеспечения законности и обоснованности возбуждения уголовного дела. - М., 1973. - C. 14

2 Подробнее об этом см.: Проблемы нарушений уголовнопроцессуальных норм при возбуждении и прекращении уголовных дел, способы их устранения: монография / Г. П. Химичева, О. В. Мичурина, О. В. Химичева, В. С. Мичурин. - М.: МосУ МВД РФ, 2004. - C. 52-116.
Отмеченные факты ведут не только к искажению истинного состояния преступности, ее структуры и динамики, но и причиняют ущерб конституционным правам и свободам, интересам потерпевших, не позволяют в законном праве граждан и организаций добиться наказания виновных и восстановить свои нарушенные права.

Именно поэтому, стадия возбуждения уголовного дела постоянно привлекает внимание ученых ${ }^{3}$.

Данная стадия порождает ряд дискуссионных вопросов, как в науке, так и на практике.Одним из них является определение необходимого и достаточного объема данных либо для возбуждения уголовного дела, либо для его отказа, методов производства проверки, доказательственного значения полученных сведений и т. п. ${ }^{4}$

3 См.: Жогин Н. В., Фаткуллин Ф. Н. Возбуждение уголовного дела. - М., 1961; Александров А. С., Круглов И. В. Необходимость и сущность коренной реформы досудебного производства // Уголовно-процессуальная деятельность. Теория. Методология. Практика: сборник научных статей / под ред. А. Ф. Лубина. Н. Новгород, 2001. - С. 43-44; Диваев А. Б. Установление основания для возбуждения уголовного дела о хищениях: автореф. дис. ... канд. юрид. наук. - Томск, 2005; Ковтун Н. Н. Обеспечение неотвратимости уголовной ответственности за преступление в стадии возбуждения уголовного дела: дис. ... канд. юрид. наук. - М., 1992; Попов А. П. Непосредственное обнаружение признаков преступления как повод к возбуждению уголовного дела: автореф. дис. ... канд. юрид. наук. - Н. Новгород, 1999. - С. 11 и др.

4 См.: Частнов К. С. Уголовно-процессуальные и криминалистические аспекты досудебного производства по уголовным делам о преступлениях, связанных с нецелевым расходованием бюджетных средств и средств государственных внебюджетных фондов: дис. ... канд. юрид. наук. - Н. Новгород, 2010. - С. 70. 
В частности, на стадиях предварительного расследования и судебного разбирательства, способы получения доказательств подробно регламентированы законом и имеют целый ряд гарантий их надежности, в связи с чем, именно они лучше всего служат назначению уголовного процесса. После возбуждения уголовного дела проводятся все необходимые следственные действия, судебные экспертизы, на основании которых следователем или дознавателем делается вывод о наличии или отсутствии события и состава преступления, виновности или невиновности в совершении данного деяния определенного лица. По результатам указанных следственных действий следователем принимается решение либо о составлении обвинительного заключения, либо о прекращении уголовного дела и уголовного преследования.

Таким образом, прекращение уголовного дела основывается на полностью исследованных материалах.

Стадия возбуждения уголовного дела, хотя, в определенной степени, и регламентирована нормами УПК, однако в меньшей степени. В соответствии со ст. 144 УПК РФ «Порядок рассмотрения сообщения о преступлении» при проверке сообщения о преступлении дознаватель, орган дознания, следователь, руководитель следственного органа, вправе получать объяснения, образцы для сравнительного исследования, истребовать документы и предметы, изымать их в порядке, установленном УПК РФ, назначать судебную экспертизу, принимать участие в ее производстве и получать заключение эксперта в разумный срок, производить осмотр места происшествия, документов, предметов, трупов, освидетельствование, требовать производства документальных проверок, ревизий, исследований документов, предметов, трупов, привлекать к участию в этих действиях специалистов, давать органу дознания обязательное для исполнения письменное поручение о проведении оперативнорозыскных мероприятий.

В то же время, согласно УПК РФ до возбуждения уголовного дела из следственных действий можно провести только осмотр места происшествия, местности, жилища, иного помещения, предметов и документов. Судебная экспертиза хотя и может быть назначена и произведена в соответствии со ст. 195 УПК РФ до возбуждения уголовного дела, однако, как справедливо отмечает Л. М. Володина, здесь возникают определенные вопросы. В частности, статья 198 УПК РФ предусматривает круг прав подозреваемого, обвиняемого, потерпевшего при назначении и производстве судебной экспертизы, но эти участники на данном этапе производства по делу отсутствуют. Возникают вопросы и относительно прав и обязанностей эксперта, поскольку эксперт в силу закона не наделен правом ознакомления с материалами проверки заявлений и сообщений о преступлении: он в соответствии с законом имеет право на ознакомление с материалами уголовного дела 5 .

Кроме того, как справедливо отмечает К. С. Частнов, является дискуссионным вопрос о доказательственном значении получаемых сведений на стадии проверки сообщений о преступлении ${ }^{6}$. Ряд ученых полагают, что доказательства могут быть собраны только после возбуждения уголовного дела, и, как следствие, объяснения и другие материалы, полученные в порядке ст. 144 УПК РФ, являются недопустимыми доказательствами по делу7 ${ }^{7}$ поскольку возможность их получения прямо не предусмотрена УПК РФ.

Таким образом, событие, исследованное на основании указанных материалов, нельзя признать полностью исследованным, а постановление об отказе в возбуждении уголовного дела носит лишь вероятный, но не окончательный характер.

Видимо по этой причине, встает вопрос об отказе от данного понятия. Как отметил глава МВД РФ Владимир Колокольцев на «правительственном часе» в Госдуме, понятие отказа в возбуждении уголовного дела может быть исключено из уголовного процесса. По его словам, в министерстве создана рабочая группа, задачей которой является изучение вопросов совершенствования уголовного и уголовно-процессуального законодательства, в том числе, рассматриваются новеллы вплоть до исключения из уголовного процесса понятия отказа в возбуждении уголовного дела. По мнению экспертов, это позволило бы избежать принятия необоснованных решений на самом важном, первоначальном этапе уголовного процесса.

5 См.: Володина С. М. Проблемы регламентации возбуждения уголовного дела // Библиотека криминалиста. Научный журнал. 2013. — № 4(9). - С. 8.

6 См.: Частнов К. С. Указ. соч. С. 71.

7 См.: Лупинская П. А. Основания и порядок принятия решения о недопустимости доказательств // Российская юстиция. - 1994. № 11. - С. 3; Григорьева Н. Исключение из разбирательства дела недопустимых доказательств // Российская юстиция. - 1995. № 11. - C. 5 . 
Он отметил, что подобная практика распространена во многих странах и может обеспечить более качественную защиту законных интересов наших сограждан. И что немаловажно - исключить при этом возможные злоупотребления и правонарушения со стороны самих правоохранителей ${ }^{8}$.

У данной позиции есть как сторонники, так и противники. Адвокаты говорят, что это приведет к пассивности органов дознания и нарушению прав граждан. Доследственная проверка будет проводиться небрежно, поскольку все равно никто не сможет отказать в возбуждении уголовного дела. В связи с этим, дознание будет работать спустя рукава 9 .

В то же время, отмечается, что сейчас зачастую сотрудники полиции не хотят возбуждать уголовное дело, и делают все возможное, чтобы в этом отказать, чтобы сократить количество работы, так как результаты работы меряются соотношением количества возбужденных дел и раскрытых ${ }^{10}$.

Как отмечается в прессе, отказ в возбуждении уголовного дела является наиболее распространенным итогом рассмотрения сообщения о преступлении, что является следствием «палочной системы». Решения об отказе в возбуждении уголовного дела принимаются даже в тех случаях, когда наличие признаков преступления не вызывает никаких сомнений. Практика такова, что решение о возбуждении уголовного дела принимается только в том случае, если есть уверенность в том, что преступление будет раскрыто ${ }^{11}$.

В соответствии с п.П. 5 и 6 ст. 148 УПК РФ, отказ в возбуждении уголовного дела может быть обжалован прокурору, руководителю следственного органа или в суде в порядке, установленном ст. ст. 124 и 125 УПК РФ.

Признав постановление органа дознания, дознавателя об отказе в возбуждении уголовного дела незаконным или необоснованным, прокурор отменяет его и направляет соответствующее постановление начальнику органа дознания со своими указаниями, устанавливая срок их исполнения. То же самое касается и отказа руководителя

8 CM.: URL://ria.ru/investigation/20121017/903415286.html\# ixzz2gIc95prE

9 См.: URL://www.gazeta.ru/social/2012/10/17/4815709.shtml.

10 Там же.

11 См.: URL: //zakon.ru/Blogs/OneBlog/2130. следственного органа, следователя в возбуждении уголовного дела.Отменить постановление об отказе в возбуждении уголовного дела, вынесенное следователем,руководителем следственного органа может и соответствующий руководитель следственного органа.

В то же время, как отмечается в прессе, злостность вышеуказанных нарушений проявляется в том, что после отмены постановления об отказе в возбуждении уголовного дела сотрудниками органов дознания спустя определенное время вновь выносится такое же постановление. В связи с этим, делается вывод, что деятельность органов дознания по-прежнему направлена на укрытие преступлений от учета и создание ложного представления о положительных результатах своей работы у вышестоящего руководства. Реформа системы МВД никаких хоть сколько-нибудь значимых положительных перемен в этой сфере не принесла, что свидетельствует о ее несостоятельности ${ }^{12}$.

Определенная доля истины в этих словах есть. Материалы практики показывают, что многие граждане и организации годами не могут добиться справедливости в данном вопросе и восстановить свои нарушенные права.

Наряду с этим, следует обратить внимание и на другой аспект этой проблемы. В соответствии со ст. 150 УПК РФ, предварительное расследование производится в форме предварительного следствия либо в форме дознания. Дознание производится по делам, указанным в п. 3 ч. 1 данной статьи. По остальным делам производится предварительное следствие. Следовательно, возбуждение уголовного дела по данным статьям должно осуществляться следователями.

Из этого правила есть отдельные исключения. В частности, в соответствии со ст. 157 УПК РФ, при наличии признаков преступления, по которому производство предварительного следствия обязательно, орган дознания в порядке, установленном статьей 146 УПК РФ, возбуждает уголовное дело и производит неотложные следственные действия. Таким образом, орган дознания может возбудить уголовное дело, по которому производство предварительного следствия обязательно, но только такое, по которому необходимо производство неотложных следственных действий.

12 Там же. 
В связи с этим, практика возбуждения уголовного дела строится по следующей схеме. Сотрудники органа дознания, к которому относятся органы внутренних дел Российской Федерации и иные органы исполнительной власти, наделенные в соответствии с федеральным закономполномочиями по осуществлению оперативно-розыскной деятельности, при установлении признаков преступления в результате проведения проверки по сообщениям о преступлении либо проведения оперативно-розыскных мероприятий, направляют материалы для возбуждения уголовного дела в следственный отдел.

Достаточно часто, в особенности по делам экономической направленности, следователи в силу разных причин (нежелание проводить большой объем работы по таким делам, большой загруженности, неясности перспективы расследования уголовного дела и т. п.) «не усматривают» в указанных материалах признаков состава преступления и возвращают материалы в оперативные подразделения. В ряде случаев оперативный сотрудник не направляет материалы в следственный отдел, а приезжает на консультация по поводу возбуждения уголовного дела к следственным работникам, которые также «не усматривают» состава преступления.

В этих условиях оперативные работники вынуждены выносить постановления об отказе в возбуждении уголовного дела по надуманным и не вполне законным основаниям (не представилась возможность установления определенного лица, лицо уехало в командировку (отпуск), не проживает по адресу прописки, не получены ответы по запросам и т. п.).

При этом в соответствии с Приказом МВД России от 26 марта 2008 года № 280 «Об утверждении Положения по организации взаимодействия подразделений органов внутренних дел РФ при расследовании и раскрытии преступлений» материалы доследственной проверки должны оцениваться с точки зрения достаточности для возбуждения уголовного дела.

Статья 17 УПК РФ закрепляет основной принцип оценки доказательств, заключающийся в том, что судья, присяжные заседатели, а также прокурор, следователь и дознаватель оценивают доказательства по своему внутреннему убеждению, основанному на совокупности имеющихся в уголовном деле доказательств, руководствуясь при этом законом и совестью. Внутреннее убеждение при оценке доказательств должно быть достоверным, категоричным, единственно верным выводом на основании материалов дела, не допускающим никаких сомнений. Следователь, дознаватель, прокурор при оценке доказательств должен учитывать относимость, допустимость, достоверность, достаточность доказательств, всесторонность, полноту и объективность произведенного расследования ${ }^{13}$.

В принципе эти требования должны относиться и к оперативным работникам. Однако, в описанном выше случае, оперативные работники выносят постановление об отказе в возбуждении уголовного дела вопреки своим убеждениям о наличии в полученных ими материалах признаков составов преступления. В связи с этим, в последнее время все чаще в постановлении об отказе в возбуждении уголовного дела наряду с пунктом, предусматривающим отказ в возбуждении уголовного дела, фигурирует пункт, предусматривающий ходатайство перед прокурором об отмене постановления об отказе в возбуждении уголовного дела.

Кроме того, незаконный отказ в возбуждении уголовного дела является нарушением принципа законности. В связи с этим, виновные (в данном случае оперативные работники) могут понести наказание (чаще дисциплинарного характера) вопреки своим действиям и убеждениям.

Отмеченные обстоятельства свидетельствуют, по мнению автора, о наличии серьезных проблем в вопросе отказа в возбуждении уголовного дела.

Видимо по этим причинам в новом УПК Украины законодатель ликвидировал стадию возбуждения уголовного дела. В соответствии со ст. 214 УПК Украины следователь, прокурор безотлагательно, но не позднее одного дня после подачи заявления, сообщения об уголовном правонарушении или после самостоятельного выявления им с любого источника обстоятельств, которые могут свидетельствовать о совершении уголовного преступления, обязан внести соответствующие сведения в Единый реестр досудебных расследований и начать расследование ${ }^{14}$.

13 Об этом см.: Карпенко В. М. Оценка доказательств следователем и дознавателем в досудебном производстве по уголовным делам: монография. - М.: ВНИИ МВД России, 2009.

14 Положение о Едином реестре досудебных расследований, порядок его формирования и ведения утверждаются Генеральной прокуратурой Украины по согласованию с Министерством вну- 
Анализируя новый уголовно-процессуальный закон, юристы как Украины ${ }^{15}$, так и России ${ }^{16}$, отмечают его несовершенство в части начала процедуры расследования.

Действительно, проводить следственные действия по каждому заявлению, которые могут быть разные, в том числе глупые и абсурдные, вряд ли целесообразно.

В связи с этим, Л. М. Володина отмечает, что отказ от стадии возбуждения уголовного дела должен быть последовательным. По ее мнению, уголовно-процессуальный закон должен четко урегулировать порядок принятия и регистрации заявления или сообщения, поступившего в правоохранительные органы. Последующим шагом должно быть решение следователя (дознавателя) о принятии материалов к своему производству, которое и должно стать собственно началом производства расследования. Отказавшись от возбуждения уголовного дела по факту и начиная расследование с момента получения сообщения (заявления) о совершенном преступлении, собрав необходимые доказательства причастности конкретного лица к совершению преступления, органы предварительного расследования могли бы вынести акт возбуждения уголовного преследования конкретного лица. При этом были бы решены и иные проблемы уголовного процесса (признание лица подозреваемым, применение к нему мер уголовно-процессуального принуждения (задержание, меры пресечения, иные меры принуждения) $)^{17}$.

В целом с данными предложениями можно согласиться.

В то же время, представляется, что порядок принятия и регистрации заявления или сообщения, поступившего в правоохранительные органы, регламентирован достаточно полно. Осуществляя проверку заявлений и сообщений, правоохранительные органы могут сделать предварительную оценку полученных материалов. В случае, если в таких материалах не усматривается признаков преступления, они списываются в архив. Если, по их мнению, в материалах усматриваются признаки преступления, такие материалы направляются в следственные органы, которые начинают расследование.

Соответственно должны быть внесены определенные изменения в уголовно-процессуальный кодекс. тренних дел Украины, Службой безопасности Украины, органом, осуществляющим контроль за соблюдением налогового законодательства.

15 См. Корж В. П. Проблемы расследования преступлений в условиях нового Уголовно-процессуального кодекса Украины // Актуальные проблемы расследования преступлений: материалы Международной науч.-практич. конференции (Москва, 23 мая 2013 г.). В 2 ч. Ч. 2. - М.: Изд-во ООО «Буки Веди», 2013. C. $170-172$

16 См.: Юрчишин В. Н. Новый УПК Украины уполномочил прокурора быть процессуальным руководителем досудебного расследования // Библиотека криминалиста. Научный журнал. - 2013. № 3(8). - C. 202-205.
17 См.: Володина Л. М. Указ. соч. С. 10-11. 